\title{
Avaliação mutagênica do canabidiol, um composto da maconha, por meio dos testes citogenéticos do micronúcleo e do cometa
}

\section{Mutagenic evaluation of cannabidiol, a marihuana compound, by micronucleus and comet assay cytogenetic tests}

\author{
Leni Gomes da SILVA ${ }^{1}$
}

\begin{abstract}
SILVA, L. G. Avaliação mutagênica do canabidiol, um composto da maconha, por meio dos testes citogenéticos do micronúcleo e do cometa. Dissertação (mestrado) - Faculdade de Medicina da Universidade de São Paulo. Departamento de Medicina Legal. Área de concentração: Medicina Legal. Orientadora: Gilka Jorge Fígaro Gattás. Saúde, Ética \& Justiça, 5/7(1-2):37-9, 2000-2002. [Resumo]
\end{abstract}

Resumo: A planta Cannabis saliva L., também conhecida como maconha, é uma das mais antigas plantas, sem interesse alimentar, cultivadas pelo homem. Apesar de ser conhecida como droga de abuso, possui muitas qualidades terapêuticas, sendo indicada principalmente como antiemético e analgésico. Porém, sua ação psicotrópica limita bastante seu uso clínico. O canabidiol (CBD), composto não psicoativo presente em grande quantidade na planta, é capaz de alterar a transmissão e resposta neuromuscular em animais de laboratório e no homem. Sua eficácia foi avaliada no controle e tratamento de convulsões, na distonia muscular e no torcicolo espasmódico idiopático. Entretanto, pouco se sabe sobre a sua ação no material genético. A avaliação do potencial mutagênico de uma droga pode ser efetuada por meio de testes citogenéticos, como o teste do micronúcleo (MN) e o teste do cometa (comet assay), entre outros. Micronúcleos são corpúsculos citoplasmáticos resultantes de quebras cromossômicas ou de cromossomos inteiros que se atrasam em relação aos demais durante a anáfase no ciclo celular. Efeitos semelhantes também podem ser detectados por meio do teste do cometa, que permite identificar fragmentos de DNA em células únicas que são arrastados para longe do núcleo principal após serem submetidos a uma corrente elétrica. Estudos preliminares demonstraram que o uso do CBD pode aumentar a freqüência de aberrações cromossômicas em linfócitos humanos tratados in vitroe alterações numéricas em eritrócitos de camundongos in vivo. Na presente investigação foi avaliada a freqüência de $\mathrm{MN}$ e de cometas em

\footnotetext{
1. Bióloga. Pós-graduanda do Departamento de Medicina Legal, Ética Médica, Medicina Social e do Trabalho da Faculdade de Medicina da Universidade de São Paulo.

Endereço para correspondência: Rua Teodoro Sampaio, 115 - São Paulo, SP. CEP:05405-000
} 
SILVA, L. G. Avaliação mutagênica do canabidiol, um composto da maconha.

linfócitos humanos mantidos em cultura com CBD, dissolvido em etanol $(0,01 \mathrm{ml} / \mathrm{m} /$ de meio $)$ nas concentrações de 0,$001 ; 0,01 ; 0,1 ; 1,0$ e $10 \mathrm{~g}$ de $\mathrm{CBD} / \mathrm{ml}$ de meio. As culturas de linfócitos foram realizadas a partir de sangue periférico de seis indivíduos com idades médias de 27,3 :t2,1 anos. A análise da freqüência de $\mathrm{MN}$ em linfócitos binucleados mantidos em cultura com a droga por 48 horas não revelou diferença estatisticamente significante $(p>0,25)$ quando comparada com as culturas controle. Por outro lado, a freqüência de cometas avaliada por análise morfológica nas culturas tratadas com CBD e etanol, incubadas por quatro horas, foi maior do que a observada nas culturas controle, sendo que as culturas controle com etanol e as culturas tratadas com $0,01 \mathrm{~g}$ de $\mathrm{CBD} / \mathrm{ml}$ de meio foram as que contribuíram de forma significante para essa diferença $(p<0,05)$. Comparações entre os resultados obtidos na avaliação morfológica e por analisador de imagem mostraram correlação estatisticamente significante $(p<0,01)$ entre os dois métodos, sugerindo a possibilidade de realização do teste do cometa, mesmo na ausência de analisador de imagem. Apesar de não ter alterado a freqüência de $M N$, o CBD, dissolvido em etanol, aumentou de maneira estatisticamente significante a freqüência de cometas, o que sugere a ação mutagênica do CBD in vitro. Considerando-se o alto consumo da maconha e o potencial terapêutico do CBD, outros testes de mutagenicidade deveriam ser realizados antes de sua possível indicação clínica.

Unitermos: Testes de mutagenicidade/métodos. Canabidiol/uso terapêutico. Canabidiol/toxicidade. Análise citogenética. Cannabis/uso terapêutico. Etanol/toxicidade. In vitro.

SILVA, L. G. Mutagenic evaluation of cannabidiol, a marihuana compound, by micronucleus and comet assay cytogenetic tests. Dissertação (mestrado) - Faculdade de Medicina da Universidade de São Paulo. Departamento de Medicina Legal. Área de concentração: Medicina Legal. Orientadora: Gilka Jorge Fígaro Gattás. Saúde, Ética \& Justiça, 5/7(1-2):37-9, 2000-2002. [Abstracts]

Abstract: The plant Cannabis sativa L., algo known as marihuana or maconha has been cultivated by man for many years. Despite its reputation as an abuse drug the plant has therapeutic qualities and has been indicated especially as an analgesic or antiemetic substance. This plant contains a considerable amount of the nonpsychoactive compound, the cannabidíol (CBD). It has been indicated as an anticonvulsant in view of the depressive effect it produces on neuromuscular transmission and response, both, in laboratory animals and in mano The efficacy of this substance, has been assessed in the control and treatment of epileptic convulsions and dystonic movement disorders. To evaluate the mutagenic potential of a drug or substance some cytogenetic tests such as the micronucleus (MN) and the comet (SCGE) assays can be performed. Micronuclei are represented by chromosomal material in the cell cytoplasm, originated from acentric fragments of DNA or complete chromosomes which failed to attach to the mitotic spindle. On the other hand, the comet assay permits the identification of DNA fragments in isolated cells that run away from the main nucleus when subjected to electrophoresis, resulting in a figure that resembles a cometo Preliminary studies have shown that the use of $C B D$ may increase the frequency of chromosomal aberrations in human lymphocytes treated in vitro, as well as numerical changes in polychromatic erythrocytes of mice, in vivo. In the present investigation, the frequency of $\mathrm{MN}$ and comets was 
evaluated in human lymphocytes exposed to CBD dissolved in ethanol $(0.01 \mathrm{ml} / \mathrm{m} /$ medium $)$ in concentrations of 0,$001 ; 0,01 ; 0,1 ; 1,0$ and $10,0 \mathrm{~g}$ $\mathrm{CBD} / \mathrm{ml}$ medium. The lymphocytes cultures were obtained from peripheral-blood samples taken from six donors, 3 mal e and 3 female, mean age 27,3 \pm 2,1 years. After 48 hours in culture the CBD dissolved in ethanol, or ethanol alone, did not increase the frequency of $\mathrm{MN}$ in binucleated lymphocytes $(p>0.25)$. However, when compared to contrai ones the culture treated with CBD dissolved in ethanol showed a statistícally significant difference in the frequency of comets. The main difference was detected in the cultures with $0.01 \mathrm{mg} \mathrm{CBD} / \mathrm{ml}$ medium. Similar results were algo observed in the cultures with ethanol. All the cells in the comet assay were analyzed by the morphological and image systems and the comparison between the two methods showed a statistically significant correlation $(p<0.01)$. These data suggest that the comet assay can be performed even if an image analyzer is unavailable. Although the $\mathrm{MN}$ frequency remained unchanged, the frequency of comets was íncreased in a statistically significant way by the CBD dissolved in ethanol - which suggests mutagenic effect of CBD in vitro. Taking into consideration the large consumption of marihuana and the therapeutic potential of the CBD, other mutageníc tests should be undertaken, especially in the in vivo systems, before this substance can be prescribed.

Keywords: Mutagenicity tests/methods. Cannabidiol/therapeutic use. Cannabidiol/toxicity. Cytogenetic analisys. Cannabis/therapeutic use. Ethanol/toxicity. In vitro. 